\title{
Validity Of Learning Devices Based On ARCS Model To Improve Mathematical Critical Thinking Ability
}

\author{
$1^{\text {st }}$ Vivi Afdarni \\ Student of Undergraduate Program of Mathematics and Natural \\ Scinece Faculty \\ UniversitasNegeri Padang \\ Padang, Indonesia \\ vivi.afdarni@gmail.com
}

\author{
$2^{\text {nd }}$ Irwan \\ Mathematics Department \\ UniversitasNegeri Padang \\ Padang, Indonesia \\ irwan@fmipa.unp.ac.id
}

\begin{abstract}
The aims of this development is to know the characteristic of mathematics lesson devices with ARCS model based to improve mathematical critical ability in grade X SMA which valid. The learning model is the ARCS model consisting of attention, relevance, confidence, satisfaction. The purpose of the ARCS model is to motivate learners in solving difficult mathematical problems. This development model used in the research is the Plomp's model (preliminary research, prototyping phase, and assessment phase). The product of learning said to be valid if the resultant learning were valid of content and construct. The instrument used in this research was a validation sheet containing aspects of presentation, content and material feasibility, graphics or display and language. Validation results of the RPP and LKPD experts are 0.965 and 0.873 with valid categories.
\end{abstract}

Keywords - ARCS Model, Learning Devices, Mathematical Critical Ability, Plomp Model

\section{INTRODUCTION}

Critical thinking is the process of searching, obtaining, evaluating, analyzing, synthesizing and conceptualizing information as a guide for developing one's thinking with self-awareness, and the ability to use this information by adding creativity and taking risks.[1] Based on the opinion of some experts, critical thinking skills are essential for learners, as today science and technology are developing very rapidly and allow anyone to obtain information quickly and easily from various sources and all over the world.[2-7].

The study of critical thinking skills developed in California and Malaysia focuses on science education [812]. One of the researches of science is the teaching of mathematics. Therefore, critical thinking skills are needed to measure how to develop learner thinking in science lessons. $[13,14]$. Previous research by researchers shows that lowschool students' critical thinking skills are still low $[15,16]$. The following problem, when the author conducted preliminary studies at the SMAN 4 Sijunjung, SMAN 9 Sijunjung and SMAN 12 Sijunjung, obtained information that the results of the mathematical aptitude and critical appraisal tests are still weak.

Based on the description of the problems above, there is a need for a learning device that can help teachers and students in the learning process in the classroom.
Implementation of unsuccessful learning cannot be separated from learning resources developed for learners to be motivated to learn mathematics $[17,18]$. One of the learning resources required is the Student Worksheet (LKPD) and Lesson Plans (RPP).

RPP is a planning program that is adapted to guide the implementation of learning to any learning activity. [19] LKPD is educational material that has been packaged in such a way that learners are expected to learn the teaching material independently.[20] Based on these opinions, the RPP and LKPD can help teacher mathematics and learners in the classroom learning to process. The author is interested in developing learning tools based on the ARCS learning model (Attention, Relevance, Confedence, Satisfaction). The ARCS learning model includes attention, relevance, confidence and satisfaction. In this learning, learners are led to follow a fun learning process. ARCS model to give priority attention to students, by adapting learning materials to the learning experience, which builds student confidence and creates a sense of satisfaction for learners, so as to achieve a result optimal learning. [21] Thus, the steps of the ARCS model can improve the critical thinking skills of mathematics learners.

This ARCS learning model has advantages that are: 1) Provide instructions, active and give directions on what to do by the student, 2) Method of presenting the material with the ARCS model is not only with the theory that its application is less interesting, 3) the design of the studentcentered form of learning; 4) the application of the ARCS model increases the motivation to repeat other less attractive materials; 5) an in-depth assessment of abilities rather than student characteristics for strategies. More effective learning. [22]. The ARCS model can increase learners' motivation in learning. [23-25]. Based on the description, the authors conducted research on the development of learning devices based on the ARCS model to mathematically improve critical thinking skills.

\section{RESEARCH METHODS}

The applied development model is a Plomp model consisting of three phases, namely the preliminary research, the prototyping phase and the evaluation phase.[26] This journal deals only with the prototyping step of RPP and 
LKPD validation. In the preliminary study conducted needs analysis, curriculum analysis, analysis of concepts and analysis of learners. Observational data collection techniques, interviews with mathematics teachers, questionnaires and initial tests with class X students SMAN Sijunjung.

The prototype manufacturing phase is realized by designing RPP and LKPD mathematics based on the ARCS model. The learning tools that have been developed are validated by 5 experts composed of 3 experts in mathematical education, an expert in educational technology and an expert in Indonesian language. Validator will provide an assessment and suggestions on the design of learning tools to identify weaknesses and strengths, and to take into account expected product specifications using validation sheets. The valid instrument includes self-assessment instruments and validation tools.

\section{RESULT AND DISCUSSION}

the preliminary study conducted needs analysis, curriculum analysis, analysis of concepts and analysis of learners. Needs analysis is done to obtain data from learners and teachers in the learning process. The results obtained are conventional learning, the learning tools used so far is a pack book, many learners who consider mathematics difficult and many less active and interested formulas and the critical thinking skills of mathematics learners are not optimal.

The curriculum analysis aims to analyze the program of two supporting aspects, namely $\mathrm{KI}$ and KD. At this point, a revision of the 2013 curriculum for high school mathematics subjects is conducted. This analysis was conducted to study the range of materials, learning objectives and materials that can be used in the ARCS model. The results of the formulation of indicators and analysis of mathematics syllabus $\mathrm{X}$ class High School organized in accordance with the indicators of achievement of skills so easily understood.

Concept analysis aims to determine the content and subject needed to develop learning tools. The results of the conceptual analysis based on the program used is that there is 1 chapter that is studied in class X of semester II which is trigonometry. Student analysis aims to determine the quality of people who can be used as a guide in designing learning tools. This analysis is taken into account in the design of the LPCPD based on the ARCS model that includes learner learning, student participation, the importance of the LKPD for learners and the description of the LKPD that learners enjoy. In this study, the learners who will serve as subjects are the students of SMA.

Prototyping phase is the device design stage based on learning features based on the ARCS model in the form of RPP and LKPD. This design is based on the preliminary results of the study that have been made. After generating the ARCS model based on RPP and LKPD, the researcher performed a self-assessment of the validity of the construct and validated with experts the validity of the content. The validity of the construction means conformity between the resulting product and the predetermined development element and the validity of the content means conformity between the resulting product and certain specified criteria. Self-assessment errors that researchers find on the product include typing errors and punctuation errors. After the selfassessment, products based on ARCS are validated by validators. Based on the results of self-assessment errors and validator suggestions, ARCS-based product enhancements include:

TABLE I. SElF-Evaluation ERror AND VALIDATOR COMMENT (BEFORE THE REVIEW)

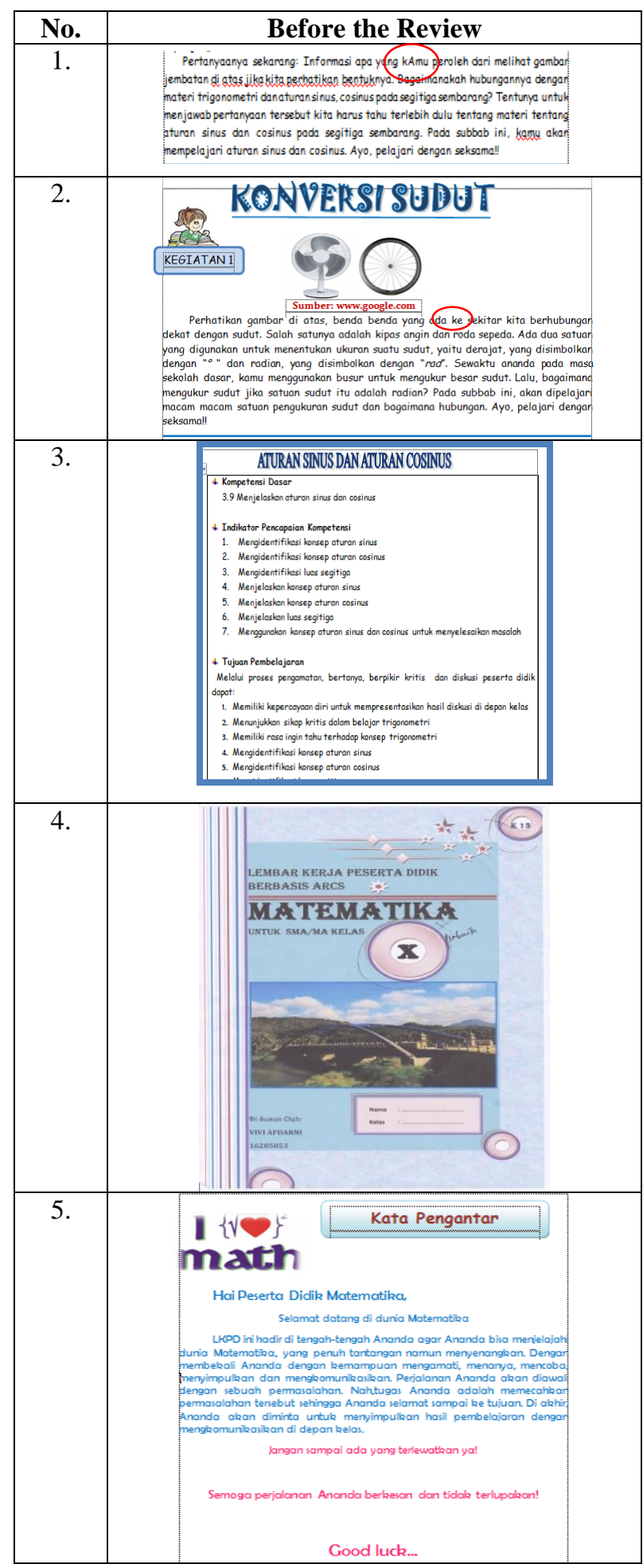


TABLE II. SELF-Evaluation ERror ERror ANd VALIDATOR COMMENT (AFTER THE REVIEW)

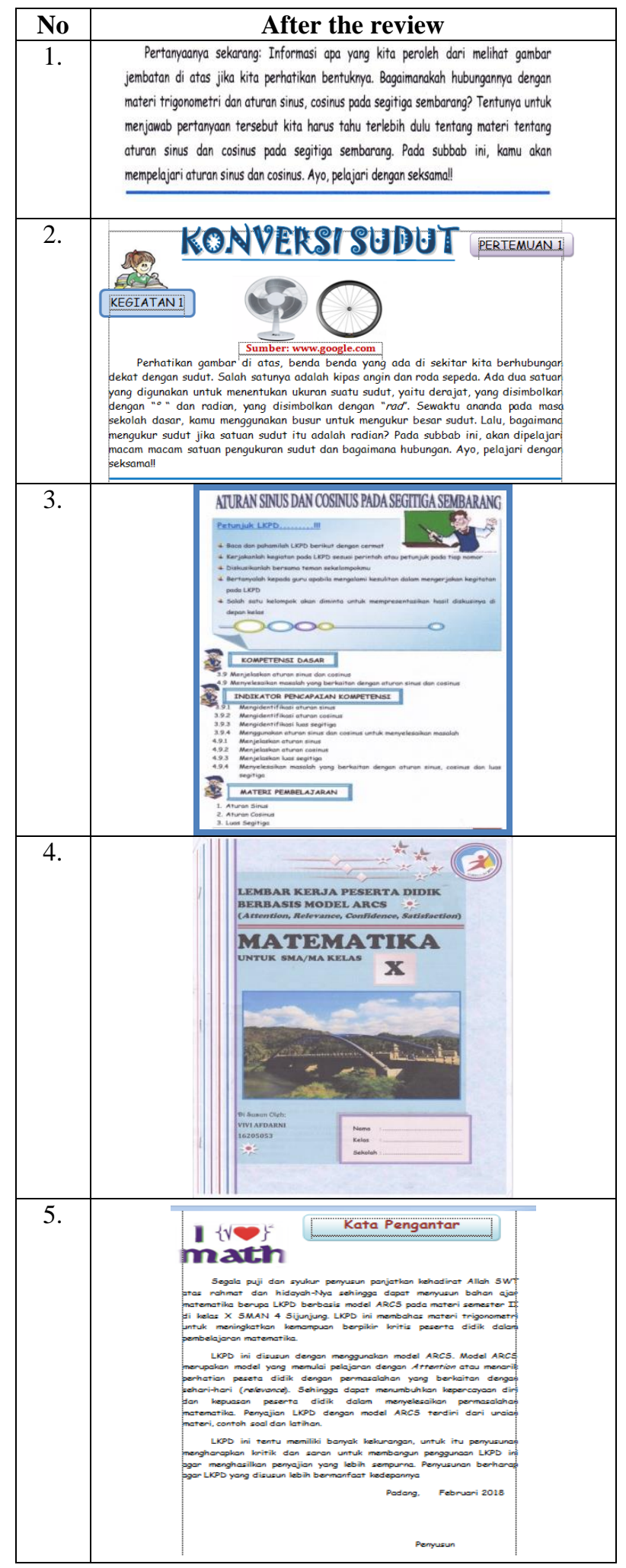

The validation of RPP is seen by the subject's identity, the formulation of learning indicators, the formulation of learning objectives, the selection of learning materials, the selection of learning strategies, the selection of teaching resources, learning stages, assessment, language and writing. The overall result of the RPP validation is 0.965 .

LKPD based on the global ARCS validated by mathematical experts met the valid criteria with the validity index on the aspect of the presentation and the aspect of the feasibility of the content is 0.926 . This means that the characteristics and relevance of LKPD with ARCS-based learning can help learners improve their critical mathematical thinking skills. Aspects of this graph or display in the validation by a lecturer of educational technology with the results of data analysis obtained 0.723 with valid criteria. In addition, the linguistic aspect in the validation by an Indonesian language lecturer with data analysis obtained 0.917 with valid criteria. The results of the global validation for each aspect can be found in Table 3 .

TABLE III. SELF VALIDATION ReSUlTS OF THE LKPD ARCS ModEL

\begin{tabular}{|c|l|c|c|}
\hline No & \multicolumn{1}{|c|}{ Aspect of Validation } & $\begin{array}{c}\text { Validity } \\
\text { Index }\end{array}$ & Category \\
\hline 1. & Presentation & 0,926 & Valid \\
\hline 2. & Didactics and content & 0,926 & Valid \\
\hline 3. & Challenge (Display) & 0,723 & Valid \\
\hline 4. & Language & 0,917 & Valid \\
\hline \multicolumn{2}{|c|}{ Average validity Index } & $\mathbf{0 , 8 7 3}$ & Valid \\
\hline
\end{tabular}

Based on Table 3, it can be seen that the average LKPD validation as a whole is 0.873 with valid criteria. Thus, it can be concluded that LKPD with ARCS-based learning has been valid.

\section{CONCLUSION AND SUGGESTION}

Based on the results of validation conducted by experts has obtained information that the development process of learning devices based on the ARCS model in the form of RPP and LKPD met the valid product criteria.

\section{ACKNOWLEDGMENT}

The authors wish to thank Dr. Irwan, M.Si. as a lecturer at Padang State University graduate who provided advice and guidance in carrying out the article. Subsequently, to the director and professor of mathematics at SMAN 4 Sijunjung who allowed and facilitated the author to conduct a research essay. This article is based on a thesis written by Vivi Afdarni titled "Developing Mathematical Learning Devices Based on an ARCS Model (Attention, Relevance, Confidence, Satisfaction) to Improve the Critical Thinking Skills of Mathematics of X-Class SMA".

\section{REFERENCES}

[1] Yildrim. B dan Ozkahraman, S., "Critical Thinking in Nursing Process and Education", Internasional Journal of Humanities and Social Science, Vol. 1, No. 13, Hal 257-262, 2011.

[2] Husnidar. Ikhsan., dan Rizal. Syamsul, "Penerapan Model Pembelajaran Berbasis Masalah untuk Meningkatkan Kemampuan 
Berpikir Kritis dan Disposisi Matematis Siswa”, Jurnal Didaktik Matematika Vol. , No. 1, April 2014, ISSN: 2355-4185, 2014.

[3] Hasratuddin, "Meningkatkan Kemampuan Berpikir Kritis Siswa SMP Melalui Pendekatan Matematika Realistik", Jurnal Pendidikan Matematika Vol. 4, No. 2, Desember 2010.

[4] Mahmuzah. Rifaatul, "Peningkatan Kemampuan Berpikir Kritis Matematis Siswa SMP Melalui Pendekatan Problem Posing", Jurnal Peluang. Vol. 4, No. 1, ISSN: 2302-5158, 2015.

[5] Fisher. Alec, Critical Thinking: An Introduction, United Kingdom: Cambrigde University Press, 2001.

[6] Ennis. Robert H., "The Nature of Critical Thinking: An Outline of Critical Thinking Dispositions and Disabilities", Makalah dipresentasikan pada Sixth Internasional Conference on Thinking at MIT, Cambridge, Mei 2011.

[7] Hassoubah. I.Z, Cara Berpikir Kritis dan Kreatif, Bandung: Nuansa, 2004.

[8] Ministry of Education, Malaysia education blueprint 2013-2025, Ministry of Education, Putrajaya, 2013.

[9] Daud. S, "Tahap Penguasaan Kemahiran Berfikir secara Kritis dan Kreatif dalam Pelajaran Sains di Kalangan Pelajar Tingkatan Dua di Sekolah Daerah Kuala Terengganu (Critical and creative thinking skills mastery level in science subjects among form two students at Kuala Terengganu school district)", Undergraduate Project Report, Universiti Teknologi Malaysia, 2004.

[10] Kamrin. S., \& Noordin. S., Tahap Penguasan Kemahiran Berfikir Kritis Pelajar Sains Tingkatan 4 (mastery level of critical thinking skills among grade 10 science students), J Educ Universiti Teknologi Malaysia, 13:58-72, 2008.

[11] Rashid AS. Ismail HN., "The effect of integrating creative and critical thinking on schools student thinking", Int J Soc Sci Humanit 4(6):518-525, 2014.

[12] Tang KN, Nair S , Prachak B., "Developing instrument to measure thinking skills and problem solving skills among Malaysia primary school pupils", Procedia Soc Behav Sci 116:3760-3764, 2014.

[13] Mapeala. Ruslan and Siew. Nyet Moi, "The development and validation of a test of science critical thinking for fifth graders", Mapeala and Siew Springer Plus. 4:741. DOI 10.1186/s40064-0151535-0, 2015 .

[14] Facione PA, Facione NC., "The California critical thinking dispositions inventory test manual", California Academic Press. Milbrae, 1992.

[15] Syahbana. Ali, "Peningkatan Kemampuan Berpikir Kritis Matematis Siswa SMP Melalui Pendekatan Contextual Teaching And Learning", Jurnal JNPM (Jurnal Nasional Pendidikan Matematika), April 2012, Vol. 02, No.01, 2012
[16] Jumaisyaroh. Tanti., Napitupulu. E and Hasratuddin, "Peningkatan Kemampuan Berpikir Kritis Matematis dan Kemandirian Belajar Siswa SMP Melalui Pembelajaran Berbasis Masalah”, Jurnal Kreano, ISSN: 2086-2334, Vol. 5, No. 2, Bulan Desember 2014, 2014.

[17] Maylistiyana. Dhika Elvira, Hobri dan Susanto, "Pengembangan Lembar Kerja Siswa (LKS) dan Rencana Pelaksanaan Pembelajaran (RPP) Materi Perbandingan dan Skala Berbasis Scientific Approach yang Berorientasi Problem Based Learning (Development of Students Worksheet and Lesson Plan for Ratio and Scale Materials based on Scientific Approach with Problem Based Learning Orientation)", Jurnal Edukasi Vol. 3, No. 1, 2016.

[18] Waluyo. Eko, Sa'dijah. Cholis, dan Subanji, "Pengembangan RPP dan LKPD berbasis Realistic Mathematics Education dengan memerhatikan beban kognitif Siswa Materi Bangun Ruang Sederhana Kelas IV SD”, Jurnal Pendidikan, Desember 2016, Vol. 1, No. 12, 2016.

[19] Sanjaya. Wina, Perencanaan dan Desain Sistem Pembelajaran, Jakarta: Kencana Prenada Media Group, 2008.

[20] Prastowo. Andi, Panduan Kreatif Membuat Bahan Ajar Inovatif, Jogjakarta: DIVA Press, 2010

[21] Irsaf. Zulfira, "Penerapan Model ARCS untuk Meningkatkan Hasil Belajar Siswa Kelas VII SMP Labschool Universitas Tadulako Pada Materi Sudut-Sudut Segitiga", Jurnal Elektronk Pendidikan Mtematika Tadulako, Volume 01 Nomor 02, Maret 2014, 2014.

[22] Aryawan. I., "Pengaruh Penerapan Model Pembelajaran Attention, Relevance, Confidence, Satisfaction (ARCS) dan Motivasi Berprestasi Terhadap Hasil Belajar IPS pada Siswa Kelas V Sekolah Dasar Negeri di Gugus XIII Kecamatan Buleleng”, Dalam e-Journal Program Pascasarjana Universitas Pendidikan Ganesha, Vol, 4. Page 1-11, 2014.

[23] Farida. Annisatul, "Penerapan Model Pembelajaran ARCS (Attention, Relevance, Confidence, Satisfaction) Pada Mata Kuliah Matematika Diskrit di Program Studi Teknik Informatika STMIK Duta Bangsa", Jurnal Sains Tech Politeknik Indonusa Surakarta, ISSN : 2355-5009, Vol. 1, Nomor 5, Bulan Juni Tahun 2016.

[24] Lusiyani. Ina, "Implementasi Model Pembelajaran Matematika Attention Relevance Confidence Satisfaction (ARCS) dengan memanfaatkan Barang Bekas sebagai Media Pembelajaran Untuk Meningkatkan Kemampuan Beripikir Kritis dan Kreatif', Tesis tidak diterbitkan, Surakarta: Universitas Muhammadiyah Surakarta, 2012.

[25] Sulistiyani, "Efektivitas pembelajaran ARCS (Attention, Relevance, Confidence, Satisfaction) Berbantuan Alat Peraga terhadap Peningkatan Hasil Belajar Matematika Peserta Didik Pokok Bahasan Segiempat", Tesis tidak diterbitkan, Semarang: UIN Walisongo, 2011.

[26] Plomp. T dan N. Nieveen, "Educational Design Research", Enshede: Netherlands Institute For Curriculum Development (SLO), 2013. 